\title{
Legal System Development in the 21st-Century Era
}

\author{
Muhammad Rafi Darajati ${ }^{1}$, Muhammad Syafei ${ }^{2}$ \\ \{rafidarajati@untan.ac.id ${ }^{1}$,muhammad.syafei@hukum.untan.ac.id² \\ Universitas Tanjungpura, Indonesia ${ }^{12}$
}

\begin{abstract}
Law is a normative institution that gives effect to the society, the law also receives the influence and impact of its society. One of the important issues is how the law to maintain survival amidst the changing times. The modern era can't be avoided by any country including Indonesia. This article aims to see the direction of the legal system in the era of globalization, including in Indonesia. The results show that entering into the era of globalization, where among countries in the world increasingly borderless, there is a tendency to convert the legal system, because there is not really a perfect legal system, all the legal system have positive and negative points.
\end{abstract}

Keyword: Globalization; Law; Convergence

\section{Introduction}

Nowadays, there is not only one legal system is exist, but various legal systems. Two legal systems that are very recognizable are the Civil Law System and the Common Law System. In addition to these two, many other legal systems are worthy of bearing a legal system, such as the Islamic legal system, the Chinese legal system, the Japanese legal system, the legal systems of African countries. Within the legal system, there are various elements, regarding this, there is Friedman's theory which is quite well known that the elements of this legal system are legal substance, legal structure, and legal culture[1]

Between this legal system and its scope, there is a close relationship, namely the relationship of interaction or mutual exchange between the two. This means that in addition to the law is a normative institution that gives influence to the environment, and it also receives the influence and impact of the environment. One crucial problem faced by every system is how to maintain survival amid the pull of these changes. This challenge can be answered by providing answers in the form of adapting to these changes to maintain their survival or fail to adapt to these changes. It is especially entering the modern era like today, where changes are swift, and the impact of these changes is quite significant.

Any country, including Indonesia, cannot avoid developments in this modern era. The Indonesian legal system, as a result of its historical development, is compound. They have so- 
called because up to now in Indonesia, several legal systems have their patterns and arrangements. The legal system is the customary law system, the Islamic law system, and the civil law system. These combination means the merging of the three values of the legal system,

even though the three values of the legal system have different philosophical and sociological foundations. Even so, the Indonesian legal system has its style, namely the existence of the 1945 Constitution and Pancasila[2]. It is not an easy task to realize a national law for the Indonesian people, which consists of various ethnic groups with different cultures and religions, and the diversity of laws left by the former colonial government. The development of national law will apply to all citizens regardless of the religion they hold must be done carefully. In order not to become a broken legal system due to being unable to adapt to the times, it is necessary to make a revolutionary adjustment. Therefore, in this article, we will look at the trends of the legal system in the 21 st century and the development of the legal system in Indonesia.

\section{Method}

This study used a descriptive qualitative research method. Methods of collection using observation techniques, document study. The data analysis techniques used are data reduction, data presentation and conclusion drawing. In this study, the method used is legal research in empirical studies, by looking at law as a reality that includes social, cultural, and other realities.

\section{Result and Discussion}

\section{Legal System dan Legal Tradition}

The legal system is an organized, structured unit consisting of elements or parts that interact with one another and work together for the interests and objectives of the unit. Experts on legal comparison no longer distinguish the existence of a legal system in the world only between the common law system (Anglo-American legal system) which is dominated by unwritten and precedent laws (previous court decisions) with civil law (Continental Europe Legal System) which is dominated by laws and regulations. However, at this time regarding the legal system, there are already more varied differences, namely (Ali: 2008, 203):

1. Civil law, which applies in Europe and the countries of the former colonies. According to this legal system, the law must be codified as the basis for the enactment of a country's law so that legal certainty is created. Countries that adhere to this civil law system have complete and continuously updated laws to determine everything that can be brought to justice, such as the application procedure (procedural law) and the appropriate punishment for each violation (material). The role of the judge here is to establish the facts of the case and apply which articles can be met with the resolution of the case[3].

2. Common law, which applies in the United Kingdom, the United States, and Commonwealth countries. In this legal system, there is no known standard or codified legal source, so that community habits are developed or have been decided by the court, which is the source of the law. In this system, the judge has a significant role in shaping the law.

3. Customary law, which is widely applicable in several African countries, China and India

4. Islamic law, which applies in Islamic countries, especially in the Middle East 
5. A mixed legal system applies to Indonesia, which applies positive legal systems, customary law, and Islamic law.

In a modern legal system, there must be a variety of sources of the law so that the benchmarks for identifying law will vary and usually include a written constitution, the provisions of the legislature, and judicial precedents (Hart: 1997, 157). When discussing the legal system, it will not be separated from the theory of Lawrence M. Friedman about the legal system. Where the legal system is described as having three elements, namely (Friedman: 1975, 18):

1. Legal substance, where it is a rule, norms, and patterns of real human behavior in the system. The legal substance also includes output produced by individuals who are in the system in the form of new rules or decisions.

2. The legal structure is a fixed framework or part and gives limits to law enforcement agencies. It is also said that structure is one of the essential and tangible elements of the legal system. In Indonesia, the legal structure can be described in the form of advocates, prosecutors, judges, and police.

3. Legal culture is an atmosphere of mind in a social system that can determine how the law is used, avoided, or even abused by the community.

As a comparison, Sunaryati Hartono divides the elements of the legal system into twelve elements, such as (1) philosophy, (2) substance or legal material, (3) the whole legal institutions, (4) legal processes and procedures, (5) human resources, (6) legal education system, (7) organizational structure and system and coordination among legal institutions, (8) office equipment of legal institutions, (9) software such as proper implementation instructions, (10) legal information, (11) legal awareness and behavior of the legal community, and (12) state budget that is provided for carrying out the duties of legal institutions and carrying out professional legal development (Mahfud MD: 2012, 21).

The next part is the legal tradition; the word "tradition" comes from the Latin language, which means transfer or forwarding so that the tradition is a continuous repetition of an action. In law, this tradition is something that has reached us now from the past. The form of tradition from the right side is information and will enable those who receive it to provide diverse analyses to understand the function of the tradition itself again[4].

The legal tradition can distinguish between the characteristics of one legal system with other legal systems so that through seeing from the legal tradition can be identified about different legal families. However, although differences can be identified, it is not easy in practice, a country has a pure legal tradition to form its legal system without a mixture of other legal systems. Through several influences, both historically, politically, and economically, a country's legal system is often an amalgamation of various legal systems, which means incorporating elements of different legal traditions[5]. This legal tradition is something that has taken root and historical attitudes that condition the nature of the law, about the role of law in society and government, about the organization and operation of the legal system, and about the way these must be created, applied, studied, perfected, and taught[6].

This paper will focus on the Indonesian legal tradition, where three main legal traditions have an essential influence on the development of law in Indonesia. The legal traditions are customary law, Islamic, and western legal traditions. The customary law tradition is believed to have lived since the early formation of the indigenous people in the archipelago. As a form of legal tradition, customary law has three bases. First, namely in its form as a prescription, customary law consists of various interrelated institutions in society; second, as a rule, customary law is a directive to obey a specific rule in the institution concerned; and third, in its 
form as an interpretation of a decision, customary law is what arises in the decision of indigenous people functionaries (Lukito: 2013, 7).

The other legal tradition is the Islamic legal tradition, where Islamic law is sourced from the Qur'an and the Hadith. Islamic law is complete at the theoretical level so that it can be used to handle cases that have not even occurred. Islamic law is not made to meet human needs, but human needs are expected to submit to God's will. The propagators of Islam in Indonesia can be quite successful with the marked absence of resistance because propagators of Islam combine Islamic legal values with other legal traditions in Indonesia. The encounter of harmonization between Islamic legal traditions and legal traditions in Indonesia today can be seen from, for example, at the time of marriage, divorce law, banking law, inheritance law.

The third legal tradition is the civil law tradition. This legal tradition was brought by the Dutch when they colonized Indonesia. The main idea of the legal tradition is to separate the relationship between law and religion so that elected representatives will form the government, and the main task of the government is to recognize and defend the people's rights. The civil law tradition only recognizes laws and regulations as a source of law. Therefore, the acceptance of the tradition of civil law is quite complicated because it collides with various legal traditions adopted by the indigenous people of Indonesia at that time (traditional law traditions). The method of transferring the tradition of civil law carried out by the Dutch is by using the principle of concordance whereby the codification principles carried out by the Dutch in his country were transferred to the colony, one of which was Indonesia.

These three legal traditions are the embryos of the current Indonesian legal system, where Indonesia takes what is right from these legal traditions and adapts to the values that live in Indonesian society and current conditions. This proves that a country's legal tradition will be in line with the country's history.

\section{Legal System Development}

The legal system is dynamic in the sense that it develops continuously. Therefore, the elements or parts of the legal system can be changed and replaced without affecting the continuity or sustainability of the system. These changes are in line with the interests or the nature of human beings who are changing every time. So the system must be able to adjust.

The discoveries in the field of technology are increasingly making countries in the world increasingly borderless. This resulted in the growth of a new pattern of division of labor that no longer saw the world fragmented into large and small countries, each with a different national economic system, but came to understand that the world as a global market and a planet which is inhabited by one species of creature, namely humans (Hartono, 1991, 67). Also, the formation of regionally-based joint markets will further develop the globalization flow; one example is the formation of the ASEAN Economic Community, where the integration program is a reaction to globalization's challenges. In this case, globalization implies market growth and financial transactions[7].

Globalization means a process that tends to create an integrated world economic order, create a single ecological system, and create a communication network that covers the entire world (Twinning: 2000,4). Globalization is a means to compete genuinely, and the law exists to protect the competition so that undesirable things do not occur. The effects of globalization also result in the diminishing meaning of the country's sovereignty. Whereas this country's sovereignty is a sharp differentiator between its national problems and international problems, state sovereignty can be a bastion of the intervention of other countries' intervention on their national problems (Parthiana: 2003, 79). The depletion of state sovereignty is due to the 
emergence of problems which also contain two dimensions, namely the national and international dimensions, where these two dimensions are interrelated and inseparable, for example, the problem of violations of human rights by a state against its citizens is no longer a national problem. Regulations on human rights are more universal applications, where the protection of human rights such as physical security, freedom of speech, and freedom of religion, must be the same in any part of the world. In the future, it can be predicted that more and more legal norms based on careful scientific research and then are recognized internationally as a rule of international law or universal values will also be accepted and infused into national law.

Globalization causes the convergence of the legal system. Convergence is an attempt to unify legal systems, conceptions, principles, or norms (Budhijanto: 2014, 96). The implications of globalization will force the legal order to converge so that economic efficiency is achieved. A legal system can look different because they have different doctrines and institutions, but the difference is meant only on the surface because basically, the institution in question is still able to fulfill the same and similar functions. The conception of convergence is based on the understanding that while there may be differences between legal systems at the level of conceptual problems, functional solutions to the problems tend to be similar.

According to some experts from international relations and international law, the critical factor for the convergence of law is a paradigm shift in the world where the state authorities at this time very often carry out various interactions at the international level, wherefrom the frequency of interactions there will be legal convergence[8]. It can be said that no one runs a pure legal system at this time in a country, both common law and civil law. This is seen in the practice in various countries in the world, making loans between the contents of one system to another. For example, some say that in the criminal justice system in Western Europe, there is no longer anyone who entirely runs the common law and civil law systems. In this case, it can be seen that from one system to another, there is no better one, all of which have positive and negative points so that when merging from the positive points of all, it will produce a robust, efficient and fair system[1].

\section{Indonesia Legal System Development}

Based on history, the Indonesian legal system can be said to be a mixture of traditional legal traditions which are legal traditions that existed before colonialism by the Dutch; Islamic legal traditions brought by Islamic propagators from the Middle East, and the civil legal traditions brought by the Dutch when they colonized Indonesia. Indonesia as adopting a Mix Legal System because the legal realities in Indonesia impose: Legislation (Civil law characteristic), Customary Law, Islamic law and the existence of the Religious Courts in Indonesia, Indonesian judges in practice follow jurisprudence[9].

Furthermore, when Indonesia became an independent state, there was a legal unification so that only one system was applied, namely the national legal system. Indonesia's national legal system is a legal system that applies throughout Indonesia, which includes all legal elements (such as content, structure, culture, facilities, laws and regulations, and all its sub-elements), which are interdependent and are sourced from the 1945 Constitution.

The reason for the 1945 Constitution as sources of national legal are the first; the 1945 Constitution contains the objectives, grounds, ideals of the law, and basic norms of the Indonesian state, which must be the aims and footing of legal politics in Indonesia. The second is that the 1945 Constitution contains distinctive values derived from the views and culture of the Indonesian nation, which were passed down by ancestors for centuries. In contrast, the 
reason for Pancasila as the basis and state ideology is very suitable to be used as a platform of shared life for the nation of Indonesia, which is very diverse in order to remain tightly bound as a united nation. Secondly, Pancasila is contained in the opening of the 1945 Constitution in which there is a statement of independence by the Indonesian people. In its position as an adhesive or unifier, Pancasila has been able to reposition itself as a place to return if the Indonesian nation is threatened with division. Pancasila is the root, culture, and value orientation of the Indonesian nation, and must be the starting point in projecting the political direction of national law[2];[10]

In the future, the Indonesian legal system must accommodate current demands that cannot be separate from global developments, namely the adoption of universal values that transcend traditional boundaries. Indonesia's legal development must be able to meet the needs at the national level simultaneously and international pressure related to various universal standards. Its fulfillment cannot rely solely on ad hoc efforts but must be carried out sustainably and consistently and thoroughly. The more we face the 21 st century, the more our national law will show a transnational nature, so that differences with other legal systems will decrease.

Facing the fact that Indonesia is living in the intercourse among ASEAN countries, for example, it is necessary to review the relevance of the legal system of continental Europe, which has naturally been adhered to because of the influence of Dutch colonialism. Indonesia is currently among international interests that are politically and economically dependent a lot on countries that adopt a common law system[11]. Therefore Indonesia no longer needs to fortify itself with the principles that apply to the continental European legal system but also to open itself to apply the principles of the Anglo-Saxon legal system that are relevant to the needs of the Indonesian state. We cannot always rely again on the process of law formation through legislative products, which take time and huge costs. Therefore laws that grow and develop in the international community can be outlined in national legal politics through the formation of laws by governments and legislative bodies and establishment of law by judges. The influence of the Anglo-Saxon legal system to Indonesia can start from the Indonesian state's activities in associating at the international level, namely by entering into international agreements both bilateral and multilateral. The influence can also come from the many legal experts who continue their legal studies to countries that adopt the Anglo-Saxon system to either directly or indirectly return to Indonesia to become academics and practitioners, practices, or understandings about the anglo Saxon legal system.

As a paradigm of legal development, Pancasila as an ideology of the Indonesian state has at least four guiding principles which must be used as guidelines in the formation and enforcement of the law in Indonesia[12]. First, the law must protect the whole nation and guarantee the nation's integrity; therefore, no laws are allowed to set the roots of disintegration. Second, the law must be able to guarantee universal justice by giving particular potential to the weak so that they are not exploited in free competition against influential groups. Third, the law must build democracy in line with the rule of law. Fourth, the law must not be discriminatory based on any primordial ties and must encourage the creation of diverse tolerance based on humanity and civilization.

\section{Conclusion}

In the era of globalization, where states become borderless, there is a tendency for convergence of the legal system, because there is no perfect legal system, all of which have positive and negative points. A legal system can look different because they have different doctrines and institutions, but the difference is meant only on the surface because basically, the institution in question is still capable of fulfilling the same and similar functions. The 
convergence of the legal system can make the law more effective and efficient. Regard to the development of the legal system in Indonesia, initially, the legal system in Indonesia was a customary law system. The influence of the Islamic legal system and the civil legal system, make the legal system in Indonesia is a mixed legal system. The presence of common law, which has given its color enlightenment to the law in Indonesia. The presence of various legal systems is expected to respond to various needs in Indonesian society in anticipating the globalization. Of course, all the legal system in Indonesia must be based on Pancasila and the 1945 Constitution so that they still have their characteristics.

\section{References}

[1] V. O'Connor, "Practitioner's Guide Common Law and Civil Law Traditions," Int. Netw. to Promot. Rule Law, 2012.

[2] G. Lestari, "Bhinnekha Tunggal Ika : Khasanah Multikultural," J. Pendidik. Pancasila dan Kewarganegaraan, 2015.

[3] J. Dainow, "The Civil Law and the Common Law: Some Points of Comparison," Am. J. Comp. Law, vol. 15, no. 3, 1966.

[4] H. P. Glenn, "Doin' the Transsystemic: Legal Systems and Legal Traditions," Mcgill Law J., vol. 50, 2005.

[5] D. Zartner, "The Culture Of Law: Understanding The Influence Of Legal Tradition On Transitional Justice In Post-Conflict Societies," vol. 22, no. 2, 2012.

[6] D. C. Jones, "Mongolia, Law Convergence, And The Third Era Of Globalization," Washingt. Univ. Glob. Stud. Law Rev., vol. 3, p. 63, 2004.

[7] H. Yoshimatsu, "The Challenge of Globalization, Business Interests and Economic Integration in ASEAN", this paper was presented at the ASEAN 40th Anniversary Conference, Ideas and Institutions: Building an ASEAN Community?," 2007.

[8] Crettez, Bertrand, B. Deffains, and O. Musy, "Legal Convergence And Endogenous Preferences," International Review of Law and Economics," vol. 39, 2014.

[9] M. P. Zenno, "PENERAPAN PRINSIP ULTIMUM REMEDIUM DALAM TINDAK PIDANA KORUPSI," J. Yudisial, 2017.

[10] J. Bertrand, "Indonesia's quasi-federalist approach: Accommodation amid strong integrationist tendencies," Int. J. Const. Law, vol. 5, no. 4, pp. 576-605, 2007.

[11] U. Bosma, "Commodification and Slavery in the Nineteenth-Century Indonesian Archipelago," J. Soc. Hist., vol. 54, no. 1, pp. 109-124, 2020.

[12] A. K. Pandey, “The Truth About Article 370.," J. Const. Law Jurisprud., pp. 40-42, 2019. 